\title{
TIMING, ORDER AND DURABILITY OF NEW
PRODUCT ADVANTAGES WITH IMITATION

HUN LEE ${ }^{1 *}$, KEN G. SMITH ${ }^{2}$, CURTIS M. GRIMM ${ }^{2}$ and AUGUST
SCHOMBURG ${ }^{3}$
'School of Management, George Mason University, Fairfax, Virginia, U.S.A.
${ }^{2}$ Robert H. Smith School of Business, University of Maryland at College Park,
College Park, Maryland, U.S.A.
${ }^{3}$ Kogod College of Business, American University, Washington, D.C., U.S.A.

This research examined the effects of timing, order and the durability of first mover advantages by analyzing the stock market reactions to new product introductions and imitations. The major findings are that both timing and order of moves are important and that rival reactions undermine the durability of first mover advantages. More specifically, (1) early and fast movers achieve greater gains than late and slow movers, and (2) first movers suffer at the time of new product imitations. Copyright (C) 2000 John Wiley \& Sons, Ltd.

A special case of first mover research involves the introduction of a new product. A firm that is first to introduce a new product theoretically realizes monopoly profits by being the only player in a particular niche of the marketplace (Lieberman and Montgomery, 1988; Nelson and Winter, 1982; Porter, 1985; Schumpeter, 1934, 1950). However, whether these first mover monopolistic advantages are temporary or more durable will be largely determined by the responses of rivals. By quickly imitating new product introductions, rivals can adversely affect the durability of the first mover advantages by sharing and/or reducing their potential profits (D'Aveni, 1994; Lieberman and Montgomery, 1988; Porter, 1985; Schumpeter, 1934, 1950). Moreover, in some instances, a fast second move can produce results superior to those of the first mover (Baldwin and Childs, 1969; Connor, 1988; Smith, Grimm, and Gannon, 1992).

One important stream of new product research has focused on the stock market reactions to new

Key words: competitive dynamics; first mover advantage; entry order; timing; new products

* Correspondence to: Professor Hun Lee, MSN 5F5, Enterprise Hall 209, School of Management, George Mason University, Fairfax, VA 22030, U.S.A. product introductions (Chaney, Devinney, and Winer, 1991; Eddy and Saunders, 1980; Wittink, Ryan, and Burrus, 1982). For example, Chaney et al. found that firms realize a significant positive shareholder wealth effect at the exact time of new product introduction announcements. While this new product research has been important, it has ignored the consideration of timing and order of new product moves, and the durability of first mover advantages under condition of competitive imitations (Kerin, Varadarajan, and Peterson, 1992). Yet, these are the very factors that often determine the success of new product introductions (D’Aveni, 1994).

The goal of the present research is twofold. First, we seek to advance our understanding of the new product introduction process by exploring the performance consequences of move timing, order and imitation. In particular, we examine the shareholder returns of these new product introductions because such measures can be more closely linked to the actual timing (e.g., Bettis and Weeks, 1987). This is an especially important consideration when the net advantages of these introductions may be short-lived due to competitive imitation, which is increasingly the norm today (D'Aveni, 1994). That is, traditional coarsegrained year-end measures of performance may

\author{
Final revision received 26 April 1999
}


fail to capture the shorter-term dynamic effects of moving first, or fast, when these benefits are undermined by rapid competitive imitation. Secondly, we assess the effects of competitive imitation on the durability of returns to the first mover. Specifically, we study the extent to which competitive imitation erodes the performance benefits of first movers. The next section offers two hypotheses: one dealing with move timing and order effects and the other with the durability of first mover advantages.

\section{HYPOTHESES}

\section{Timing and order effects}

This research focuses on two related temporal aspects of new product behavior: move timing and order. ${ }^{1}$ Move timing represents the elapsed time between the date of a new product introduction and the date of each imitation; move order reflects the rank order position of new product moves starting with the first mover to the last imitation. Our contention is that imitations will vary in terms of timing and order, and that this variation can have important performance consequences for both the first mover and the imitators.

In theory, the first firm to introduce a new product in the marketplace gains an advantage by securing a temporary monopoly market position due to the imitator's lag. The length of this lag depends on the first mover's ability to impede reaction (D'Aveni, 1994; Nelson and Winter, 1982). Lieberman and Montgomery (1988) and Porter (1985) identify the potential impediments to imitative responses in their discussions of first mover advantages. First moving firms can potentially exploit experience/learning curve effects, which permit first moving firms, relative to late imitators, to reduce costs through actual experience in activities such as new product manufacturing. Preemption of scarce resources can be another obstacle to imitation whereby pioneering firms secure supply of essential raw materials and establish preferential shelf space, distribution

\footnotetext{
${ }^{1}$ There is an obvious relationship between move timing and order. For example, if a first move occurred on day one and there were subsequent imitations in each of the next four days (days two through five) then move timing and order would be perfectly correlated. We are interested in how and in what ways move timing and order each impact performance.

channels, and product segment before late imitators. First movers can also create buyer awareness and switching costs that hinder successful imitation.

While the first mover literature argues in favor of moving first, a number of scholars have promoted early imitation as a profitable alternative to moving first (Baldwin and Childs, 1969; GalOr, 1985; Kamien and Schwartz, 1978; Katz and Shapiro, 1987; Smith et al., 1992; Teece, 1986). Early imitators may learn from the first mover's experience, such as reducing or avoiding development and testing costs and pricing mistakes (Baldwin and Childs, 1969; Drucker, 1985). Drucker (1985) identified several advantages to following including limiting risk exposure and cutting development cost by reverse engineering. Connor (1988) also suggests that market leaders may intentionally wait to introduce a new product until a rival product comes to market first. This strategy allows the market leader to avoid cannibalization of current products but at the same time to minimize late mover penalties. Thus, first movers will only develop modest advantages and exploitation before the imitators respond quickly and aggressively.

Regardless of whether one endorses moving first or imitating early, clearly firms that are slow or late to imitate rivals' new product introductions will be at a competitive disadvantage. Thus, investors should value fast movers and early imitators ahead of slow and late movers.

Hypothesis 1: (a) The faster a firm introduces a new product, the higher the abnormal returns, and (b) first and second movers will, on the average, report higher abnormal returns than late movers.

\section{Durability of first mover advantages}

The first mover can significantly affect rivals' competitive positions (D'Aveni, 1994; Porter, 1980; Smith et al., 1992). Therefore, to the extent the new product introduction is successful, competitors are expected to imitate. ${ }^{2}$ Although

\footnotetext{
${ }^{2}$ Although one can propose that new products may fail as a result of ineffective strategy implementation, this paper focuses on the erosion of first mover advantages in instances where the new product introduction is judged as successful, by virtue of it being imitated by rivals.
} 
Schumpeter $(1934,1950)$ proposed that large returns exist for innovative behavior, he also argued that imitators can erode the profits of pioneers by sharing and/or reducing the monopoly profits. Thus, the first mover's advantage erodes in the perennial gale of competition. D'Aveni (1994) proposed that every advantage eventually evaporates, particularly in hypercompetitive environments. Thus, the durability of first mover advantages should be affected by rival responses.

Coyne (1986) and Kerin, Mahajan, and Varadarajan (1990) identify conditions that affect the durability of first mover advantages. They note that over time, the durability of the first mover's offerings will be affected by the ability of the first mover to retain the value of key product attributes over later entrants' offerings. In addition, if rivals are able to imitate quickly the attributes or cost advantages of the first mover's offerings, then the sources of competitive advantage will be short-lived.

We expect that whether the first mover advantages are temporary or more durable will, in part, be determined by the speed of rivals' imitation. By quickly imitating a new product introduction, rivals may cut into or share the advantages of the first movers. If the imitation is fast, the durability of first mover advantage will be short. In other words, the first mover's advantage would be eroded by imitation. If the imitation is slow, the first mover's advantage will be more durable. Thus, investors should de-value or lower the returns to the first mover, to a greater degree, under conditions of fast imitation as opposed to slow imitation.

Hypothesis 2: (a) At the time of new product imitations, the abnormal returns will be negative for the first movers, and ( $b$ ) the faster $a$ firm imitates, the greater the negative abnormal returns for the first mover (or the less durable the first mover advantages).

\section{METHODS}

\section{New product introduction and imitation sample}

The sample of new product introductions and respective imitations for this study was drawn from the long distance telecommunications, personal computer, and brewing industry from 1975 to 1990. The period of study was selected since this was the time in which the long distance telecommunications and personal computer industries emerged, and when the brewing industry changed from a commodity/price based industry to a more product driven industry; thus new product rivalry played a significant role in each industry.

The new product introductions and imitations used to test the hypotheses in this study were identified from a structured content analysis of Predicasts F\&S Index United States. A new product introduction is defined as a product or service category that did not exist prior to the announcement date. Some examples of new product introductions include dry beer, fiber optics, and the 386 microprocessor chip. For this study, the first article to report the introduction of a new product that previously did not exist in the industry was considered the first moving firm and the date of introduction was recorded; these firms are designated as the first movers. As noted, each new product introduction represented a product category that did not exist prior to the announcement date.

The second step was to identify all imitative responses to the initial new product introductions. The first article that reported the introduction of a product that was the same or imitative of an already existing competitor's product was considered the first imitation and the date of imitation (time) was recorded; these firms are designated as the second movers. Subsequent imitative responses were identified in the same manner and placed accordingly in response timing and order. ${ }^{3}$

\footnotetext{
${ }^{3}$ After the identification of new product events, we proceeded to validate and check the reliability of the data with three experts from each industry. The experts selected possessed industry experience for the majority of the sixteen-year study period and held responsible management or professional positions in their respective industries. Their titles included vice president for research, director of public affairs, chief of analysis, assistant division director, division administrator, and regional sales manager with leading firms in the industry, trade associations, or the U.S. Government. Experts were asked to rate the accuracy of the data for each new product introduction (first movers and all imitators) on a five point Likert-type scale from one (extremely inaccurate) to five (extremely accurate). The mean of the responses to the questions for all 82 new product events was 4.073. Analysis of variance was used to compute the reliability of the average ratings of the three experts in each industry. The average inter-rater reliability ( 3 for each industry) was 0.847 out of a possible 1.0. This is an extremely high degree of reliability for these rating (Ebel, 1951).
} 
The final step was to match the new product moves to the stock market returns at the precise date of each respective new product introduction or imitation. This final procedure limited the sample size for two reasons. First, the first moving and imitative firms needed to be traded on the U.S. stock exchanges (New York Stock Exchange, American Stock Exchange, and NASDAQ), and to have available daily returns in the file of the Center for Research in Security Prices (CRSP). Second, it was necessary that there were no other new product introductions by the same firm and/or other important firm-specific announcements regarding earnings, dividends, mergers, or acquisitions from 2 days before to 2 days after as reported in the Wall Street Journal Index.

Following these procedures, the sample for testing Hypothesis 1 (the timing and order effects), included 45 first movers, 22 second movers, and 38 later movers and the associated shareholder wealth effects at the time of each product move $(\mathrm{N}=105$ : 35 brewing, 30 long distance, and 40 personal computer). The sample developed to test Hypothesis 2 (the durability effects), included a sample of 77 first movers and the respective shareholder wealth effects at the time of associated imitation ( $\mathrm{N}=77: 21$ brewing, 16 long distance, and 40 personal computer).

\section{Event study methodology}

Event study methodology (Brown and Warner, 1985; McWilliams and Siegel, 1997) was employed to test shareholder wealth effects of competitive new product introductions and imitative responses. We computed the cumulative abnormal returns (CARs) and standardized cumulative abnormal returns (SCARs) for a 5-day trading period consisting of 2 days before to 2 days after the announcement. The SCARs served as the dependent variable for the study. Although we report the results for the 3-day and 5-day event windows, we used the 3-day event window $(-1$ to +1$)$ for our hypotheses' testing. The 3day event window is chosen to capture the possible leakage prior to and dissemination after the publication of a new product announcement. The short window is used because long windows may lead to false inferences about the significance of an event (McWilliams and Siegel, 1997).

The daily excess returns for common stocks are obtained for the period beginning 260 days prior to the announcement of a new product move to 60 days past. The event window of 60 days before and 60 days after the event was analyzed for abnormal stock returns. The methodology used to test the hypotheses is based on the market model technique to measure abnormal stock returns. This technique regresses security returns against the overall return on the market ( $\& \& P$ $500)$ to generate a series of expected returns. The estimated period for calculating expected (predicted) return is composed of 200-day returns beginning with event day $\mathrm{t}=-260$ and ending with event day $\mathrm{t}=-61 .^{4}$

\section{Move timing and order}

Move timing is defined as the number of days elapsed between the date of the new product introduction and the date of each imitation. For example, a first mover's new product introduction is given a value of 1 , denoting the introduction takes place on day 1. An imitative response 100 days later is designated as day 101. Move order is defined as the temporal rank position of an imitator compared with the first mover and other imitators. For example, the first mover is designated as order 1 , the second mover is designated as order 2, and subsequent laggards are designated in the same manner.

\section{Industry controls}

The research controlled three dimensions of industry context: concentration, sales growth, and

\footnotetext{
${ }^{4}$ The formula for the predicted return is specified as follows (for a 200-day estimation period): $\mathrm{R}_{\mathrm{pit}}=\alpha_{\mathrm{i}}+\beta_{\mathrm{i}} \mathrm{R}_{\mathrm{mt}}+\varepsilon_{\mathrm{it}}$, where $\mathrm{R}_{\text {pit }}=$ predicted returns for security $\mathrm{i}$ on day $\mathrm{t}, \alpha_{\mathrm{i}}=$ regression intercept for firm i, $\beta_{i}=$ regression slope for firm $\mathrm{i}, \mathrm{R}_{\mathrm{mt}}=$ return on the market $(\mathrm{S} \& \mathrm{P} 500)$ at time t, and $\varepsilon_{\mathrm{it}}$ $=$ disturbance term. The initial announcement appearing in the Predicasts F\&S Index Unites States is labeled as event day $\mathrm{t}=0$. The trading days prior to the event day are labeled $\mathrm{t}=-1, \mathrm{t}=-2$, and so on, and subsequent trading days are labeled $\mathrm{t}=1, \mathrm{t}=2$, and so on. The event window of $\mathrm{t}=-60$ days before and $t=60$ days after the event is analyzed by comparing the predicted returns to the actual returns. Thus, the formula for the dependent variable of abnormal return (AR) is specified as follows (for 121-day period): $A_{\text {it }}=R_{\text {ait }}$ $-R_{\text {pit }}$, where $A R_{i t}=$ abnormal return of firm $i$ on day $t, R_{\text {ait }}$ $=$ actual common stock return of firm $\mathrm{i}$ on day $\mathrm{t}$, and $\mathrm{R}_{\mathrm{pit}}=$ predicted common stock return of firm $i$ on day $t$. The abnormal returns are standardized by its standard deviation to compute the standardized abnormal returns (SAR). The cumulative abnormal returns (CARs) are computed by summing abnormal returns over a particular time interval (e.g., period of 1 day before to 1 day after the announcement).
} 
profitability. Concentration is the share of industry sales produced by the four leading firms in the industry for each year of the analysis. Sales growth is the percent change in industry gross sales from the previous year's gross sales for each year of the analysis. Profitability is the percent of total industry net income to industry gross sales for each year of the analysis. Annual data for each of the three industries were collected from various sources: BAR/LNA MultiMedia Service ADD \$ Summary, Federal Communications Commission records, FCC News, Statistics of Communications Common Carriers, Standard \& Poor's Industry Surveys, Standard and Poor's Marketing Services department, Standard \& Poor's Predicasts' Base Book, trade association records, and trade publications. Industry dummy variables were also included as controls.

\section{RESULTS}

Move timing and order effects (Hypotheses 1ab). We used cross-sectional regression analysis to study the effects of move timing and order and industry context on shareholder wealth. The results are reported in Table $1 .^{5}$ Separate regression models were performed to examine the two related dimensions of a new product move: timing and order (3-day CAR: $\mathrm{r}=0.46, \mathrm{p}<$ $0.01, \mathrm{~N}=105)$. The timing results of Model 1 suggest that the faster a firm introduces a product vis-à-vis rivals, the greater the shareholder wealth effect (3-day t-statistic $=-2.00, \mathrm{p}<0.05$ ); these results support Hypothesis 1a. The order results of Model 2 also support the timing results in that first and second movers achieve greater shareholder wealth effects than late movers (3-day tstatistic $=2.11, \mathrm{p}<0.05)$; these results support Hypothesis $1 b$.

Durability of first mover advantages (Hypotheses 2a-b). To test the durability hypotheses, we performed two analyses. First, we conducted a t-test to assess the effects of imitation on first mover advantages. Consistent with Hypothesis 2a, at the time of imitations, first movers experience a negative shareholder wealth effect with a 3-day CAR of $-0.69 \%$. The

\footnotetext{
${ }^{5} \mathrm{R}^{2}$ is a measure of goodness of fit of a particular model, and a small $\mathrm{R}^{2}$ is does not necessarily mean that there is no association between the variables (Kmenta, 1986; Norusis, 1990).

expected negative reaction for the first movers at the time of imitations is marginally significant ( $t$ statistic $=-1.45, \mathrm{p}<0.10)$.

To examine the durability hypothesis in more detail, we conducted an analysis of the first movers' net gains (i.e., the gains from introducing a new product minus the losses at the time of imitative responses). In a sub-sample of first movers with matching early (second movers) and late (late movers) imitative responses, the first movers experienced a positive 3-day reaction of $2.17 \%$ at the time of introduction (t-statistic $=2.28, \mathrm{p}$ $<0.05)$. However, these first movers experienced a negative reaction of $-0.96 \%$ at the time of early, and a negative reaction of $-1.31 \%$ at the time of late imitative responses, thus yielding a net loss of $-0.10 \%$. The group mean differences of the first mover's gains at the time of introduction were significantly different from the first mover's losses at the time of early imitation $(\mathrm{t}-$ statistic $=2.52, \mathrm{p}<0.01)$, at the time of late imitation $(\mathrm{t}$-statistic $=2.61, \mathrm{p}<0.01)$, and from the net effect (t-statistic $=1.90, \mathrm{p}<0.05)$. Thus, this sub-sample analysis provides additional support that the durability of first mover advantages erodes with imitation.

Next, we examined the effects of speed of imitation on the durability of first mover advantage. Correlation analysis suggests that timing of imitations does not significantly influence the durability of shareholder wealth for the first movers and does not support Hypothesis 2b (3-day CAR: $\mathrm{r}=-0.10, \mathrm{p}=0.39, \mathrm{~N}=77$ ).

Finally, we refer again to Table 1 to report the industry control variables. The influence of industry context was captured by dummy variables for each industry and by independent variables including industry concentration, sales growth, and profitability. Although the industry dummies were not significant, the regression analysis (combining first, second, and late movers) demonstrates the influence of industry sales growth. Namely, the shareholder wealth effects are greater when there is higher growth in industry sales.

\section{DISCUSSION}

The purpose of this study was to advance our understanding of the new product introduction process by considering the performance effects 
Table 1. Regression results for move timing, move order, and industry context ${ }^{\mathrm{a}}$

\begin{tabular}{|c|c|c|c|c|}
\hline \multirow{2}{*}{$\begin{array}{ll} & \text { Event window } \\
\text { Variables } & \end{array}$} & \multicolumn{2}{|c|}{ (3-day: -1 to +1 ) } & \multicolumn{2}{|c|}{ (5-day: -2 to +2$)$} \\
\hline & Model 1 & Model 2 & Model 1 & Model 2 \\
\hline Time & $\begin{array}{l}-0.193 \\
(-2.00)^{*}\end{array}$ & & $\begin{array}{l}-0.162 \\
(-1.62)+\end{array}$ & \\
\hline $\begin{array}{l}\text { Order dummy } \\
\text { (first \& second movers }=1 \text {, late } \\
\text { movers }=0 \text { ) }\end{array}$ & & $\begin{array}{l}0.200 \\
(2.11)^{*}\end{array}$ & & $\begin{array}{c}0.146 \\
(1.49)+\end{array}$ \\
\hline Industry concentration & $\begin{array}{l}-0.034 \\
(-0.13)\end{array}$ & $\begin{array}{r}0.033 \\
(0.12)\end{array}$ & $\begin{array}{l}-0.088 \\
(-0.32)\end{array}$ & $\begin{array}{l}-0.034 \\
(-0.12)\end{array}$ \\
\hline Industry sales growth & $\begin{array}{l}0.295 \\
(2.80)^{* *}\end{array}$ & $\begin{array}{l}0.289 \\
(2.75)^{* *}\end{array}$ & $\begin{array}{l}0.247 \\
(2.27)^{*}\end{array}$ & $\begin{array}{l}0.243 \\
(2.22)^{*}\end{array}$ \\
\hline Industry profitability & $\begin{array}{l}02.59 \\
(1.00)\end{array}$ & $\begin{array}{r}0.258 \\
(1.00)\end{array}$ & $\begin{array}{l}-0.236 \\
(-0.88)\end{array}$ & $\begin{array}{l}-0.243 \\
(-0.90)\end{array}$ \\
\hline \multicolumn{5}{|l|}{ Industry dummy } \\
\hline Brewing & $\begin{array}{c}0.394 \\
(1.68)+\end{array}$ & $\begin{array}{r}0.361 \\
(1.56)\end{array}$ & $\begin{array}{r}0.013 \\
(0.53)\end{array}$ & $\begin{array}{l}-0.020 \\
(-0.09)\end{array}$ \\
\hline Long distance telecom. & $\begin{array}{r}0.203 \\
(0.64)\end{array}$ & $\begin{array}{r}0.115 \\
(0.37)\end{array}$ & $\begin{array}{r}0.302 \\
(0.93) \\
(0.84)\end{array}$ & $\begin{array}{r}0.230 \\
(0.71)\end{array}$ \\
\hline $\begin{array}{l}\text { Personal computer } \\
\mathrm{R}^{2}\end{array}$ & $\begin{array}{r}(-0.02) \\
0.142\end{array}$ & $\begin{array}{r}(-1.20) \\
0.146\end{array}$ & $\begin{array}{r}(0.84) \\
0.079\end{array}$ & $\begin{array}{r}(0.38) \\
0.076\end{array}$ \\
\hline $\mathrm{F}$ & $2.70 *$ & $2.79 *$ & 1.41 & 1.34 \\
\hline
\end{tabular}

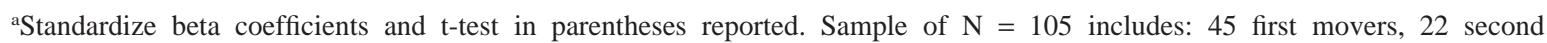
movers, and 38 late movers, and $\mathrm{N}$ for each industry includes: 35 brewing, 30 long distance telecommunication, and 45 personal computer.

$* * \mathrm{p}<0.01, * \mathrm{p}<0.05,+\mathrm{p}<0.10$

Table 2. First movers' cumulative abnormal returns $(\mathrm{CARs})^{\mathrm{a}}$

\begin{tabular}{lcc}
\hline & \multicolumn{2}{c}{ Event window } \\
\cline { 2 - 3 } Subgroups & (3-day: -1 to +1$)$ & (5-day: -2 to +2$)$ \\
\hline First movers' returns at the time of imitation ${ }^{\mathrm{b}}$ & $-0.69 \%$ & $-0.47 \%$ \\
Matching sub-sample of first movers' returns & $(-1.45)+$ & $(-0.70)$ \\
At the time of new product introduction & $2.17 \%$ & $2.42 \%$ \\
& $(2.28)^{*}$ & $-0.57 \%$ \\
At the time of early imitation & $-0.96 \%$ & $(-0.68)$ \\
& $(-1.28)+$ & $-1.09 \%$ \\
At the time of late imitation & $-1.31 \%$ & $(-0.95)$ \\
Net effect & $(-1.40)+$ & $0.76 \%$ \\
\hline
\end{tabular}

${ }^{\mathrm{a}} \mathrm{T}$-test in parentheses reported.

${ }^{\mathrm{b}} \mathrm{N}=77$

${ }^{\mathrm{c}} \mathrm{N}=24$

$* * \mathrm{p}<0.01, * \mathrm{p}<0.05,+\mathrm{p}<0.10$ 
of new product move timing and order, and the durability of these effects in the face of competitive imitation. First, the regression results confirmed the importance of move timing and order; at least for this sample, the faster and earlier a firm introduces a new product, the greater the shareholder wealth effect. We also found that competitive imitation impacts the durability of first mover advantages. Indeed, in our sub-sample analysis, we found that the first mover advantages were completely eroded by the sum effect of an early and late imitation. At the time of introduction, first movers experienced a positive 3-day reaction of $2.71 \%$. But after an early imitation, the first movers experienced a negative reaction of $-0.96 \%$ and after a late imitation, the first movers experienced a negative reaction of $-1.31 \%$, thus yielding a sum effect of $-0.10 \%$. Although the argument that one firm's action can significantly influence rivals has existed in the literature since the early writings of Schumpeter (1934), this is perhaps the first empirical study to test and document such a relationship. ${ }^{6}$ Clearly, previous new product research that has not accounted for an imitation effect has omitted a crucial variable.

Although, in general, we found imitations negatively impacted the first movers, it is interesting to note that even late imitations can significantly influence the durability of shareholder wealth to the first movers. It may be that late imitators, while giving little advantage for themselves, substantially erode first mover advantages by transferring what was once a new product into a commonplace commodity. After such a strong degree of imitation, perhaps what was once a new product becomes merely a cost of doing business. D'Aveni (1994: 233) captures this phenomenon: 'All advantages erode. As competitors copy an advantage, it is no longer an advantage. It is a cost of doing business. For example, automatic teller machines do not provide a competitive advantage to banks because almost all banks offer them. Now banks need to have them to stay competitive, and they need to find new sources of competitive advantage.'

\footnotetext{
${ }^{6}$ While an alternative hypothesis is that investors should penalize the first mover at the time of the new product introduction for the expected subsequent imitation, this does not appear to be the case.
}

Overall, our main contributions are in the two key empirical findings. First, previous research on new product introductions has largely ignored the effects of competitive dynamics or the imitation responses of rival firms. Our research then advances prior new product event studies by incorporating key aspects of new product rivalry, namely the effects of move timing, order and imitation. Second, the impact of imitation on the first mover effect, the durability hypothesis, which includes the analysis of and finding of a significant 'net effect,' is an important empirical contribution. Indeed, we find that the effect of imitation is to dissipate the first movers' shareholder wealth gains, thus undermining the durability of first mover advantages. This finding highlights the criticality of understanding competitors, especially those who will imitate, and the need for managers to recognize that many new product advantages will be temporary and critically dependent on the nature of competitive responses.

In summary, these findings imply that moving first to introduce new products results in the greatest shareholder wealth gains. Moreover, it is possible for rivals to undermine the shareholder wealth gains of first movers by imitation. As such, the results provide an incentive for further research on the competitive dynamics of new product introductions.

\section{ACKNOWLEDGEMENTS}

We thank Chuck LaHaie, Marty Gannon, Richard Kolodny, Cormac Mac Fhionnlaoich, Bill Maloney, Steve Michael and two anonymous reviewers for their help with this research.

\section{REFERENCES}

Baldwin, W. L. and G. L. Childs (1969). 'The fast second and rivalry in research and development', Southern Economic Journal, 36, pp. 18-24.

Bettis, R. A. and D. Weeks (1987). 'Financial returns and strategic interactions: The case of the instant photography', Strategic Management Journal, 8(6), pp. 549-563.

Brown, S. J. and J. B. Warner (1985). 'Using daily returns: The case of event studies', Journal of Financial Economics, 14, pp. 3-31.

Chaney, P. K., T. M. Devinney and R. S. Winer (1991). 'The impact of new product introductions 
on the market value of firms', Journal of Business, 64, pp. 573-610.

Connor, K. R. (1988). 'Strategies for product cannibalism', Strategic Management Journal, Summer Special Issue, 9, pp. 9-26.

Coyne, K. P. (1986). 'Sustainable competitive advantage - what it is, what it isn't', Business Horizons, 29, pp. 54-61.

D'Aveni, R. A. (1994). Hypercompetition: Managing the Dynamics of Strategic Maneuvering. Free Press, New York.

Drucker, P. F. (1985). 'Entrepreneurial strategies', California Management Review, 27, pp. 9-25.

Ebel, R. L. (1951). 'Estimation of the reliability of ratings', Psychometrika, 16, pp. 435-458.

Eddy, A. and G. Saunders (1980). 'New product announcements and stock prices', Decision Sciences, 11, pp. 90-97.

Gal-Or, E. (1985). 'First mover and second mover advantages', International Economic Review, 26, pp. 649-653.

Kamien, M. I. and N. L. Schwartz (1978). 'Potential rivalry, monopoly profits and the pace of inventive activity', Review of Economic Studies, 45, pp. 547-557.

Katz, M. L. and C. Shapiro (1987). 'R\&D rivalry with licensing or imitation', American Economic Review, 77, pp. 402-420.

Kerin, R. A., V. Mahajan and P. R. Varadarajan (1990). Contemporary Perspectives on Strategic Market Planning. Allyn and Bacon, Boston, MA.

Kerin, R. A., P. R. Varadarajan and R. A. Peterson (1992). 'First-mover advantage: A synthesis, conceptual framework, and research propositions', Journal of Marketing, 56, pp. 33-52.
Kmenta, J. (1986). Elements of Econometrics. Macmillan, New York.

Lieberman, M. B. and D. B. Montgomery (1988). 'First-mover advantages', Strategic Management Journal, Summer Special Issue, 9, pp. 41-58.

McWilliams, A. and D. Siegel (1997). 'Event studies in management research: Theoretical and empirical issues', Academy of Management Journal, 40, pp. 626-657.

Nelson, R. R. and S. G. Winter (1982). An Evolutionary Theory of Economic Change. Harvard University Press, Cambridge, MA.

Norusis, M. J. (1990). SPSS Statistical Data Analysis. SPSS Inc., Chicago, IL.

Porter, M. E. (1980). Competitive Strategy: Techniques for Analyzing Industries and Competitors. Free Press, New York.

Porter, M. E. (1985). Competitive Advantage: Creating and Sustaining Superior Performance. Free Press, New York.

Schumpeter, J. A. (1934). The Theory of Economic Development. Harvard University Press, Cambridge, MA.

Schumpeter, J. A. (1950). Capitalism, Socialism and Democracy. Harper, New York.

Smith, K. G., C. M. Grimm and M. J. Gannon (1992). Dynamics of Competitive Strategy. Sage, Knobbier Park, CA.

Teece, D. J. (1986). 'Profiting from technological innovation: Implications for integration, collaboration, licensing and public policy', Research Policy, 15, pp. 285-305.

Wittink, D., A. Ryan and N. Burrus (1982). 'New products and security prices', working paper, Cornell University, Ithaca, NY. 